\title{
Long-term eustatic cyclicity in the Paleogene: A critical assessment
}

Ekaterina E. Plyusnina ${ }^{\mathrm{a}}$, Dmitry A. Ruban ${ }^{\mathrm{a}, \mathrm{b}}$, Clinton P. Conrad ${ }^{\mathrm{c}}$, Geise de Santana dos Anjos Zerfass $^{\mathrm{d}}$, Henrique Zerfass ${ }^{\mathrm{e}}$

${ }^{a}$ Department of Tourism, Higher School of Business, Southern Federal University, 23-ja linija Street 43, Rostov-na-Donu, 344019, Russia

${ }^{\mathrm{b}}$ P.O. Box 7333, Rostov-na-Donu, 344056, Russia (for postal communication)

${ }^{c}$ Department of Geology and Geophysics, SOEST, University of Hawaii at Manoa, 1680 EastWest Road, Honolulu, HI 96822, USA

${ }^{\text {d }}$ Petróleo Brasileiro S/A - CENPES/PDGEO/BPA, Av. Horácio Macedo 950, prédio 20, 1100, Cidade Universitária, Ilha do Fundão, 21941-915 Rio de Janeiro, RJ, Brazil

${ }^{\text {e }}$ Petróleo Brasileiro S/A - Petrobras University/ECTEP/PCGEO, Rua Ulysses Guimarães 565, 20211-225 Rio de Janeiro, RJ, Brazil

* Corresponding author

E-mail address: ruban-d@mail.ru (D.A. Ruban)

Telephone number (corresponding author): +7(903)4634344 (D.A. Ruban)

\begin{abstract}
Global sea level has changed cyclically throughout Earth's history due to a variety of mechanisms that operate on a variety of timescales. Here we attempt to place constraints on "actual" number of sea-level cycles that can be interpreted directly from the eustatic reconstructions. We apply an interpretative algorithm to Paleogene sea level records and identify
\end{abstract}


three orders of eustatic cycles longer than $1 \mathrm{Ma}$. However, the three-ordered cyclicity might not represent cycles of global eustatic change. First, only cycles of the highest of the established orders (with a timescale of 10s of Ma) are coherent among different sea-level records. Second, the interepreted cycles are not supported by the compilation of the regional maximum flooding surfaces. Third, climatic history alone cannot explain the eustatic changes. Fourth, the interpreted cyclicity differs significantly from what is known about the tectonic control of eustasy. Fifth, there may be other orders higher than those established. The problem is rooted in 1) the fact that eustatic curves might not necessarily reflect the global events (e.g., fluctuations shown on these curves may be artifacts related to regional tectonic activity) and 2) the possible weakness of the Paleogene (especially Eocene) eustatic cyclicity and its significant "overprint" by the regional tectonic activity. Our attempted analysis claims for significant improvement of the available eustatic reconstructions. Unfortunately, the regional stratigraphical data remain still insufficient to develop any alternative eustatic curve that can be further interpreted to understand the number of the "actual" cycle orders.

Key words: Eustatic curve; Cyclicity; Paleogene; Palaeoclimate; Plate tectonics.

\section{Introduction}

Global sea level changed dramatically during the Paleogene, and these changes are documented by the available eustatic curves (Vail and Hardenbol, 1979; Hallam, 1984; Haq et al., 1987; Abreu and Anderson, 1998; Haq and Al-Qahtani, 2005; Miller et al., 2005a; Kominz et al., 2008; Müller et al., 2008; Ruban et al., 2012; Spasojevic and Gurnis, 2012; Ruban, 2016). Although aspects of the chronology, magnitude, and mechanisms of these fluctuations remain controversial (Müller et al., 2008; Ruban et al., 2012), all above-mentioned curves indicate cyclic patterns of Paleogene eustatic change (Fig. 1). This cyclicity (to be distinguished from 
rhythmicity and periodicity) is typically linked to a fixed hierarchy of cyclic processes that affect eustatic change (Read, 1995; Veeken, 2006; Haq, 2014). For instance, global sea-level changes occurring over hundreds of millions of years have been attributed to the so-called "Wilson's cycles" (e.g., Cogné and Humler, 2008), whereas cyclicity occurring over tens and hundreds of thousands of years has been linked to changes in the Earth's astronomical parameters and the socalled "Milankovitch cycles" (e.g., Miller et al., 2005a; Boulila et al., 2011; Coughenour et al., 2013; Hinnov, 2013; Ruban, 2015). Moreover, an interplay between glacioeustatic and tectonic mechanisms may affect global sea-level change on different time scales (e.g., Lovell, 2010; Conrad, 2013; Rowley et al., 2013), producing a complex cyclic pattern. Particularly, it cannot be excluded that the "actual" number of cycle orders may differ from the "ideal" number inferred from the expected number of sea-level change mechanisms operating simultaneously. This idea does not mean that the various mechanisms that define the "ideal" sea-level cycle hierarchy are not operating with their expected magnitudes and rates (e.g., Gale et al., 2008; Boulila et al., 2011). Instead, understanding the possible differences (or their absence) between the "actual" and "ideal" cycle hierarchies should facilitate further deciphering of various stratigraphic records and construction of globally-consistent sea-level curves. This understanding should help us to realize how the interplay of various eustatic controls can change the "actual" signature of the "ideal" cyclicity.

In this paper, we examine several original global sea-level curves in order to recognize the possible long-term Paleogene eustatic cyclicity. Our goal is to establish the number of orders of "actual" sea-level cycles, i.e., those directly interpreted from the eustatic curve. Although it is difficult to guarantee that the available curves actually represent global sea-level variations (e.g., Müller et al., 2008; Ruban, 2015, 2016), the urgency of such an analysis is underlined by recent eustasy-related disputes (Müller et al., 2008; Ruban et al., 2012), recent claims for global sedimentation periodicity (Melott et al., 2012), and the need to establish useful and reliable 
sequence hierarchies (Catuneanu, 2006; Catuneanu et al., 2011, 2012). We seriously consider possible uncertainties linked to the available eustatic reconstructions, and also discuss the validity of the interpreted "actual" cyclicity, especially in light of the primary stratigraphical data.

\section{Material and method}

\subsection{Eustatic curves}

From many available Paleogene eustatic curves (e.g., Vail and Hardenbol, 1979; Hallam, 1984; Haq et al., 1987; Haq and Al-Qahtani, 2005; Miller et al., 2005a; Kominz et al., 2008; Müller et al., 2008; Spasojevic and Gurnis, 2012), we choose only those recent, high-resolution records that are based on field geologic data (not modelling). Additionally, only curves indicating absolute global sea-level changes are chosen. Three reconstructions are considered for the purposes of the present analysis, namely those made by Haq and Al-Qahtani (2005), Miller et al. (2005a), and Kominz et al. (2008).

Haq and Al-Qahtani (2005) not only provide important data on sea-level changes on the Arabian Platform, but also update to the famous global curve proposed 25 years ago by Haq et al. (1987). The reconstruction by Kominz et al. (2008) is based on data and methods other than those by Miller et al. (2005a), and thus the two can be considered independent of each other. The original reconstruction by Haq et al. (1987) was criticized, particularly, by Miall (1992) and Hallam (2001) for the possible regional tectonic influences on sea-level changes judged to be global, the reconstruction by Miller et al. (2005a) was questioned by Müller et al. (2008) and by Kominz et al. (2008), who noted that local vertical motion of the New Jersey shoreline may affect the interpretation of this record in terms of global eustasy. It seems to be difficult, perhaps impossible, to avoid the influence of individual regional records (affected by tectonic activity and sedimentation dynamics) on the data employed for development of the modern eustatic 
curves (Moucha et al., 2008; Lovell, 2010). Nevertheless, such curves must serve as indicators of eustatic fluctuations until "new-generation" curves, which avoid regional effects, can be developed (e.g., Ruban et al., 2012). It should be added that, in our opinion, eustatic curves developed on the basis of "single" locality or region may have more "problems" than those based on the global synthesis of data. However, if the reconstruction is aimed essentially to be of global importance, it can be considered so until it will be disproved.

The chosen eustatic curves differ in their temporal resolution. The reconstruction by Haq and Al-Qahtani (2005) is less detailed than those presented by Miller et al. (2005a) and Kominz et al. (2008). It appears that the resolution of the former is approximately $\sim 0.5 \mathrm{Ma}$, whereas the resolution of the two latter is $\sim 0.1 \mathrm{Ma}$. We thus suppose that the eustatic fluctuations described by Haq and Al-Qahtani (2005) may be one order higher than those described by Miller et al. (2005a) and Kominz et al. (2008). It should be added that the "long-term" eustatic curve also shown by Haq and Al-Qahtani (2005), which is constrained as a line connecting successive "short-term" highstands, is not useful for our study, because we aim to interpret original eustatic reconstructions using a different method (see below).

\subsection{Long-term cycle interpretation}

The eustatic curves by Haq and Al-Qahtani (2005), Miller et al. (2005a), and Kominz et al. (2008) provide clear evidence of multi-ordered cyclicity (Fig. 1). Taking into account their resolution, we can use these curves to delineate long-term cycles of global sea-level change (provisionally, we will consider cycles with durations of 1 Ma and more as "long-term cycles"). Here we consider not only global sea-level highstands, which was preferred by Haq and AlQahtani (2005), but lowstands as well, in order to constrain the total magnitude of eustatic fluctuations of multiple orders.

We use an interpretative algorithm as follows. For each original eustatic curve, 
successive highstands and lowstands (maximal and minimal global sea levels) are connected by the curves HS and LS respectively. Then, midpoint positions (between the HS and LS curves) of sea level are determined for time slices corresponding to every highstand and lowstand. The curve for the next order of sea-level cycling is generated by connecting these midpoint positions. This procedure is repeated until the curve ceases to display a cyclic pattern. The number of interpreted curves indicates the number of orders of the eustatic cyclicity. This simple approach permits us to establish "actual", or "natural" long-term sea-level cyclicity. However, this cyclicity actually represents eustatic changes only if all sea-level changes shown on the original curves were correctly-interpreted and really global (of course, it is difficult to guarantee this). We do not give numbers to the interpreted orders of eustatic cyclicity (that is, we avoid labels like "first-order", "second-order", etc.), because the number of orders is taken as unknown by definition.

A serious challenge for the present analysis is linked to stratigraphy. Each original eustatic curve (Haq and Al-Qahtani, 2005; Miller et al., 2005a; Kominz et al., 2008) is justified along its own time scale. Although these time scales are more or less comparable with one another and also with the modern internationally-adopted Paleogene chronostratigraphy (Gradstein and Ogg, 2004; Gradstein et al., 2004; Ogg et al., 2008; Gradstein et al., 2012a,b; see on-line: stratigraphy.org), certain differences are inevitable (see review of this problem in Ruban, 2016). The chronostratigraphical frameworks (chiefly the series, stages, and absolute time scales) presented in the original publications of these eustatic reconstructions (Haq and AlQahtani, 2005; Miller et al., 2005a; Kominz et al., 2008) do not permit precise correlation. The resulting error in direct correlation of the chosen curves (Fig. 1) may reach 2 Ma. Unfortunately, this error cannot be minimized, but it is not significant with regard to the present study: we aim to constrain the number of cyclicity orders and not the temporal coherence of the original curves. Thus, it should be sufficient to consider only the errors noted in interpretations and discussions 
presented below. In the other words, we consider each eustatic reconstruction with its own (original) time scale. Generally, the nomenclature of the Paleogene series and stages and the absolute ages of their boundaries established presently by the International Commission on Stratigraphy (Gradstein et al., 2012a,b; see on-line: stratigraphy.org) are followed in this paper.

\section{Results}

The eustatic curve proposed by Haq and Al-Qahtani (2005) permits us to interpret three orders of long-term cyclicity in the Paleogene (Fig. 2). Order A corresponds to the shortest of the long-term cycles visible on the original reconstruction. These are more or less symmetrical. Order B of the long-term eustatic cyclicity is constituted of about a dozen cycles, which differ strongly in their duration and magnitude. This cyclicity remains almost invisible during the late Eocene interval. The only cycle started and ended beyond the limits of the Paleogene is Order C, which peaked as a prominent global sea-level highstand in the early Eocene.

The curve proposed by Miller et al. (2005a) also allows us to interpret three orders of the Paleogene long-term cyclicity (Fig. 2). The cycles that constitute eustatic fluctuations shown on the original reconstruction are not considered, because their duration is not "long-term" (they are recognized at the scale of $0.1 \mathrm{Ma}$ ). The long-term cycles of Order A are both symmetrical and asymmetrical, and they differ strongly in absolute duration. Some of them lasted for only $\sim 1 \mathrm{Ma}$, whereas others were longer (up to $5 \mathrm{Ma}$ and even more). However, the majority of these cycles were 1-2 Ma in duration. A few cycles of Order B were often asymmetrical, and their duration reached $9 \mathrm{Ma}$, although they were shorter in the Oligocene. The only long-term cycle of Order $\mathrm{C}$ indicates an early Eocene highstand. The preceding global sea-level rise was less gradual than the forthcoming fall.

The curve proposed by Kominz et al. (2008) depicts eustatic fluctuations, for which three orders of long-term cycles can be interpreted (Fig. 2). As in the previous case, the global sea- 
level changes demonstrated by the original curve cannot be considered "long-term". The cycles of Order A were both symmetrical and asymmetrical. Their duration varied between $\sim 1 \mathrm{Ma}$ and 5 Ma. About five cycles of Order B can be established in the Paleogene. Their symmetry and duration (from $\sim 3 \mathrm{Ma}$ to $\sim 15 \mathrm{Ma}$ ) differ markedly, but the magnitude of the relevant global sealevel changes was more or less comparable. The only asymmetrical cycle within the early Eocene highstand marks Order $\mathrm{C}$ of the long-term eustatic cyclicity.

Comparison of the three above-presented interpretations (Fig. 2) permits us to make some interesting observations. All three original curves (Haq and Al-Qahtani, 2005; Miller et al., 2005a; Kominz et al., 2008) indicate three "actual" orders of long-term eustatic cyclicity, which are named provisionally as Orders A, B, and C. The lower resolution of the reconstruction by Haq and Al-Qahtani (2005) permits us to relate the cycles outlined by their curve to Order A interpretations from the curves of Miller et al. (2005a) and Kominz et al. (2008).

\section{Discussion}

\subsection{An absence of coherence}

The interpretations based on all three original curves (Haq and Al-Qahtani, 2005; Miller et al., 2005a; Kominz et al., 2008) indicate strong similarity of only the C-order long-term cycle (Fig. 2). In all cases, the relevant highstand occurred in the early Eocene, and the registered changes in its absolute age (Fig. 2) lie within the possible correlation error (see above). In other words, despite differences in the data and the methods used by the separate authors, all reconstructions permit us to identify the early Eocene highstand. The latter is an evidently coherent feature. This also means that the available eustatic reconstructions permit unambiguous representation of only the longest-term global sea-level changes, because no such coherence is recorded at the lower orders. The above-said allows us to question whether the Paleogene cyclicity was really multi-ordered. On the one hand, the absence of coherence of the A and B- 
order long-term cycles may mean these are "artificial", i.e., they inherit peculiarities of the different methods employed by the different specialists. On the other hand, it is possible that different A- and B-order cyclicity derived from the available eustatic reconstructions indicates the very weak appearance of such cyclicity. The latter idea requires explanation, which is given below.

The dynamics of planetary climate (shifts from "greenhouse" conditions to glaciations, and vice versa) and planetary interiors (plate tectonic processes, mantle dynamics, plume emplacement, etc.) are thought to exert important controls on the global sea-level changes (e.g., Miller et al., 2005; Catuneanu, 2006; Veeken, 2006; Müller et al., 2008; Lovell, 2010; Ruban et al., 2010, 2012; Anjos Zerfass et al., 2013; Conrad, 2013; Haq, 2014; Ruban, 2016). The abovementioned absence of correspondence of the A- and B-order long-term eustatic cyclicity between the interpretations based on the curve of Haq and Al-Qahtani (2005) on the one side and the curves of Miller et al. (2005a) and Kominz et al. (2008) on the other side may be explained potentially in the terms of palaeoclimate. "Greenhouse" conditions diminish the importance of glacioeustatic mechanisms, and tectonic mechanisms for global sea level change typically operate on timescales much longer than those of the A and B cycles (Conrad, 2013). These factors minimize the Earth's potential for global eustatic change, and instead establish conditions where the regional records of sea-level changes are not coherent because of differences in the tectonic evolution of particular regions (Ruban, 2010; Ruban et al., 2010a, 2012). The reconstructions by Haq and Al-Qahtani (2005), Miller et al. (2005a), and Kominz et al. (2008) may be overwhelmed by regional signals. This echoes the earlier critique expressed by Miall (1992) and Hallam (2001), and also matches the explanations of Müller et al. (2008). The regional records employed for the development of the eustatic curves can provide an eustatic signature that is altered or masked significantly by regional tectonic influences (e.g., in the form of dynamic topography). Several authors (e.g., Kominz et al., 2008; Moucha et al., 2008; Müller 
et al., 2008; Spasojevic et al., 2008) have warned about such a possibility.

In addition, the database and methodology applied in obtaining the above-mentioned curves is distinct. Haq and Al-Qahtani (2005) justified the sea-level curve based on data from the Arabian Platform (although their curve is not based solely on data from Arabia). Miller et al. (2005a) dealt with data from the coastal plain of New Jersey (USA) and used techniques of backstripping, as say, the effects of sediment compaction and thermal subsidence were modeled, and the paleodepth was taken into account as well. An updated version of the latter work was presented by Kominz et al. (2008), who included new wells and different treatment of the data. As some data of Haq and Al-Qahtani (2005) by one side, and Miller et al. (2005a) and Kominz et al. (2008) by the other, are from different plate tectonics contexts, it is possible that the uncorrelated cycles represent the influence of regional effects, with a probable tectonic origin. Of course, such phenomena cannot occur on very long scales because of the global tectonic influences, but previous studies of the Paleocene global transgressions and regressions (Ruban et al., 2010a, 2012) permit us to hypothesize that these phenomena can be documented at the level of stages and, probably, series. In such a case, the documented A and B orders of eustatic cyclicity may represent regional uplift and subsidence patterns at the observation locations. If this idea is confirmed, it means automatically that there is only one order (the $\mathrm{C}$ order in this paper) that can be confirmed to be part of the long-term eustatic cyclicity.

\subsection{An evidence from the summary of regional data}

The most objective knowledge about eustasy can be compiled from the regional records (e.g., Hallam, 2001; Ruban et al., 2010a, 2012). In such a case, it is sensible to compare the interpreted long-term eustatic cycles with the shoreline shifts established regionally. A preference should be given to major platform regions that are more "stable" than active island arcs or orogenic belts. Unfortunately (and surprisingly), the available stratigraphical data for the 
entire Paleogene is limited, and, thus, we cannot repeat the approach employed earlier by Ruban et al. 2010a, 2012). However, some appropriate data can be found in four major regions, namely Northwestern Europe (the sea-level curve of Hardenbol et al. (1998) was adapted to the modern time scale by Gradstein et al. (2012)), Northern Africa (interpretations are possible on the basis of the composite stratigraphical schemas presented by Guiraud et al. (2005), Arabia (new interpretation of maximum flooding surfaces and sequence boundaries was presented by Simmons et al. (2007)), and Southern Australia (shoreline shifts were interpreted by McGowran et al. (2004)). In order to make the data compatible and to avoid uncertainties linked to different geologic time scales used by the specialists and changes in this scale in the past years, we 1) emphasize on the only maximum flooding surfaces, 2) consider the only B- and C-level cyclicity, and 3) deal with those maximum flooding surfaces that match the levels of cyclicity.

The results of the comparison of the cyclicity interpreted from the original eustatic curves and the regional maximum flooding surfaces are highly ambiguous (Fig. 3). The correspondence of some regional maximum flooding surfaces indicates possible nearly-global eustatic peaks. But these peaks do not coincide well with the B- and C-order cycle peaks. There are also regional maximum flooding surfaces that do not coincide. Finally, there are cycle peaks that are not associated with common maximum flooding surfaces. What is especially surprising is the absence of concentration of the regional maximum flooding surfaces in the early and middle Ypresian, where the great $\mathrm{C}$-order highstand is registered. Taken together, these observations suggest that the interpreted B- and C-order cycles are not well supported by the regional data. The above-presented observations allow yet another important inference. "Greenhouse" conditions of the early Eocene (Zachos et al., 2001; see Fig. 2) were favourable for the "overprint" of the climatic controls of the global sea-level changes by the regional tectonic activity (such a possibility is demonstrated by Ruban et al. (2010a, 2012) by example of the Paleocene), and this resulted in the absence of the coherent maximum flooding surfaces. If so, 
there might have been not such a thing as well-pronounced eustatic cyclicity in this time.

Moreover, we think that individual maximum flooding surfaces should not be necessarily present (or at least not easily recognized) in the stratigraphic record of the Ypresian because of the same reason, although this requires further examination.

\subsection{Sea-level cycles in a greenhouse world?}

According to the available palaeoclimatological data (Kennett and Stott, 1991; Zachos et al., 2001; Miller et al., 2005b; Slujis et al., 2005; Slujis et al., 2008; Zachos et al., 2008; Gornitz, 2009; Zalasiewicz and Williams, 2012), the Paleogene was a period dominated by "greenhouse" conditions, although two glaciations (the so-called "Oi-1" and "Mi-1") marked the beginning and the end of the Oligocene Epoch. The full strength of the Cenozoic glaciation was reached in the last few millions of years of this era (Ehlers and Gibbard, 2007), but some glaciation persisted through the Paleogene Period in the Southern Hemisphere, where relatively short-termed glacial advances occurred (Zachos et al., 2001; Miller et al., 2005a; Ruban et al., 2012), and the first ice sheet appeared in the Northern Hemisphere in the middle Eocene (Polyak et al., 2010). Two remarkable events were the Paleocene-Eocene Thermal Maximum and the early Eocene climatic optimum (Zachos et al., 2001; Kent et al., 2003; Cohen et al., 2007; Pearson et al., 2007; Weijers et al., 2007; Moore and Kurtz, 2008; Retallack, 2008; Gornitz, 2009; Roberts et al., 2009; Westerhold et al., 2009; Eberle et al., 2010; Hodgson et al., 2011; Bowen, 2013; Chew and Oheim, 2013; Hyland and Sheldon, 2013; Pujalte et al., 2014). There were some other potentially significant events such as the early Paleocene hyperthermal (Ali, 2009; Bornemann et al., 2009).

Undoubtedly, glacial advances facilitated global sea-level falls, and the thermal expansion of the seawater at the times of significant warming facilitated global sea-level rises on different time scales. The comparison of the Paleogene palaeoclimatic history with the long-term eustatic cyclicity (Fig. 2) implies that the recorded C-order long-term cycle peaked in the early 
Eocene, and it can be linked to the extraordinary warmth of either the Paleocene-Eocene Thermal Maximum or the early Eocene climatic optimum (or, most probably, both). Sluijs et al. (2008) postulated that the onset of the Paleocene-Eocene sea-level rise preceded the PaleoceneEocene Thermal Maximum, which led the authors to consider a tectonic origin to the transgression, possibly the ocean floor uplift in the North Atlantic Igneous Province. It should be noted, however, that the early Eocene world did not remain abnormally warm at its entire interval; some cooling also took place (Jolley and Widdowson, 2005). A problem with climate change as an explanation for this Order $\mathrm{C}$ variation is that the ice sheets and seawater warming together only account for about 50-60 m of higher sea level (e.g., Lemke et al., 2007; Conrad, 2013), if even the presence of polar ice provides better conditions for the regional appearance of the "ideal" cyclicity (Boulila et al., 2011). If so, the amount of sea level change due to this mechanism in the early Cenozoic, when the volume of landed ice was smaller, might be even more limited, and the tectonic controls on the eustatic fluctuations should be of more importance. This means that the Paleogene climate history cannot explain (at least fully) the interpreted Corder cyclicity by definition.

It has been established presently that "greenhouse" conditions favoured aquifer-eustasy, when regressions occurred despite the warmth (Sames et al., 2016; Wendler and Sendler, 2016; Wendler et al., 2016). If this occurred in the Paleogene and, particularly, Eocene, this mechanism can explain the noted absence of maximum flooding surfaces concentration. At the same time, the aquifer-eustasy questions the available eustatic reconstructions and their interpretations (in the other words, uncertainty about this mechanism means it is too early to judge about the multiordered cyclicity of the global sea level).

\subsection{Global tectonics and sea-level cycling}

The models proposed by Müller et al. (2008) and Spasojevic and Gurnis (2012) link the 
Paleogene eustasy to the global tectonics and the mantle convection. The both models permit the reconstruction of long-term changes of the global sea level on the basis of estimates of changes in ridge volume constrained by plate tectonic reconstructions. The tectonically-constrained eustatic curve of Müller et al. (2008) differs strikingly from the interpretations of the curves of Haq and Al-Qahtani (2005), Miller et al. (2005a), and Kominz et al. (2008). For example, the early Eocene C-order long-term eustatic maximum shown by all these curves corresponds to the prominent lowstand constrained only by ridge volumes changes by Müller et al. (2008) (Fig. 2). Additionally, reconstructions of sea level based on estimates of tectonics of the time-varying influence of tectonics (e.g., Spasojevic and Gurnis, 2012; Conrad, 2013) suggest gradual longterm global sea-level fall throughout the analyzed period, and do not show the early Eocene highstand shown in our interpretations (Fig. 2).

The C-order long-term eustatic cyclicity interpreted from the original curves of Haq and Al-Qahtani (2005), Miller et al. (2005a), and Kominz et al. (2008) indicates fluctuations that lasted on the scale of tens of millions of years. If such cycles are tectonic in origin, they seem to occur on timescales shorter than the 100 million year timescales of the so-called "Wilson's cycles" (Cogné and Humler, 2008), which mark important stages in the Earth's tectonic evolution. One may suppose that very long term sea level trends associated with supercontinent cycles (Santosh, 2010; Yoshida and Santosh, 2011; Nance and Murphy, 2013; Conrad, 2013; Nance et al., 2014) may be also reflected in the interpreted long-term eustatic fluctuations. However, the noted discrepancy between the interpretations based on the available eustatic curves (Haq and Al-Qahtani, 2005; Miller et al., 2005a; Kominz et al., 2008) and the models depicting global tectonic constraints on eustasy (Müller et al., 2008; Spasojevic and Gurnis, 2012; Conrad, 2013) questions the possible relationship of long-term eustatic fluctuations and the tectonic cycles. This also questions the validity of the interpreted C-order cyclycity. 


\subsection{Other sea-level cycles?}

If it was anyway true, the C-order long-term cyclicity interpreted in this study can be treated as the first-order cyclicity, because the duration and the amplitude of the interpreted cycles appear to be more or less comparable with those of the conventional "first-order cycles" (Read, 1995; Veeken, 2006; Haq, 2014). But does this mean that there were not any other longterm eustatic fluctuations? At least, the present analysis is limited to the Paleogene, whereas answering this question would require consideration of the entire Phanerozoic and the Precambrian. Presentation of the Paleogene eustasy in such a wider perspective is attempted below, although this is a very tentative analysis.

The Phanerozoic curves proposed by Hallam (1984) and then by Haq and Al-Qahtani (2005), Haq and Schutter (2008), and Haq (2014) indicate two outstanding global sea-level highstands that occurred in Ordovician and the mid-Cretaceous. Which of them resulted in higher absolute sea level remains a subject for debate (e.g., Ruban et al., 2010b), but these highstands were the largest in the Phanerozoic record. If so, the early Eocene eustatic peak recorded in this work (Fig. 2) may be just a "lower-level" feature on the very long-term trend stretching from the mid-Cretaceous highstand to the Quaternary glaciation-related lowstand. The model of Spasojevic and Gurnis (2012) depicting tectonically-constrained global sea-level fall from the late Mesozoic to the late Cenozoic generally confirms this interpretation. However, the latter is challenged by the reconstructions of Miller et al. (2005a) and Kominz et al. (2008), which indicate the early Eocene peak as unprecedented in the Cretaceous-Quaternary history of the Earth. Several new findings should be also considered. Firstly, climatic cooling, if not minor glaciation, occurred in the mid-Cretaceous and the Late Cretaceous (Frakes and Francis, 1988; Frakes and Krassay, 1992; Alley and Frakes, 2003; Miller et al., 2005; Bornemann et al., 2008;

Galeotti et al., 2009; Russell, 2009; Boulila et al., 2011; Moriya, 2011; Bowman et al., 2013; Maurer et al., 2013; Peropadre et al., 2013; see also discussion in Haq, 2014). Secondly, the 
same took place in the Ordovician (Saltzman and Young, 2005; Gornitz, 2009; Turner et al., 2011, 2012; Cherns et al., 2013; Elrick et al., 2013; Holmden et al., 2013). If so, we can hypothesize that the Ordovician, mid-Cretaceous, and early Eocene eustatic peaks were more or less comparable, which disproves the eustatic cyclicity of the order higher than the C-order documented in the Paleogene. Of course, this hypothesis should be further tested.

The Precambrian record of the geologic history may imply eustatic fluctuations much stronger than any of those that occurred in the Phanerozoic. The lines of evidence are as follows. Firstly, the "Snowball Earth" or the "Slushball Earth" models (Kirschvink, 1992; Hoffman et al., 1998; Kirschvink et al., 2000; Eriksson et al., 2004; Eyles and Januszczak, 2004; Eyles, 2008; Brasier, 2009; Gornitz, 2009; Hoffman and Li, 2009; Gaucher et al., 2010; Micheels and Montenari, 2010; Pierrehumbert et al., 2010; Strand, 2012; Zalasiewicz and Williams, 2012; Eriksson et al., 2013; Erwin and Valentine, 2013; Young, 2013) imply severe Neoproterozoic glaciations, which should lead potentially to extremely low global sea level, although such an interpretation depends strongly on the amount of sea ice, which is a debatable issue (e.g., Brasier, 2009; Gaucher et al., 2010). It cannot be excluded that the same might have also occurred for earlier Precambrian glaciations (Eriksson et al., 2004; Eyles and Januszczak, 2004; Gardaud et al., 2012; Strand, 2012; Hoffman, 2013; Melezhik et al., 2013; Tang and Chen, 2013; Young, 2013). Secondly, the size of lithospheric plates in the Proterozoic and, especially, the Archean and the Hadean, as well as the size of the Precambrian supercontinents, was relatively small (Pesonen et al., 2003; Ernst, 2007, 2009; Komiya and Maruyama, 2007; Gargaud et al., 2012; Evans, 2013). This may imply a wider distribution of young domains of the oceanic crust than in the Phanerozoic. As younger age of the oceanic crust is an important control on the eustatic rise (e.g., Müller et al., 2008; Anderson and Anderson, 2010), the Precambrian global sea level might have reached (at least, episodically) a high position relative to the Phanerozoic and, in particular, the Paleogene, which features much larger plates (Seton et al., 2012). Such an 
interpretation is in agreement (at least, in part) with the outcome of modelling undertaken recently by Coltice et al. (2014). The above-mentioned and other peculiarities of the Precambrian tectonics (including, first of all, the activity of mantle plumes (Gargaud et al., 2012; Gerya, 2014)) likely influenced global sea-level change on a large scale; possible changes in the crust production may also induce a cyclic pattern of these changes (Eriksson et al., 2004, 2005, 2012; 2013). For the earliest times, this second line of evidence is most uncertain, because the onset of the plate tectonics on the Earth remains debatable (e.g., Hamilton, 2011; Gargaud et al., 2012; Griffin et al., 2014; Turner et al., 2014). Thirdly, the amount of water on the Earth did not remain constant at the earliest stages of the planetary evolution (Gargaud et al., 2012), which also means significant global sea-level changes (although the latter, probably, will never be modelled). Fourthly, a slow drain of water into the interiors should be considered as a long-term control on the global sea-level changes (Conrad, 2013; Maruyama et al., 2014).

If the evidence given above implies Precambrian eustatic fluctuations were more "extreme" than those of the Phanerozoic, one can hypothesize the very long-term cyclicity, which can be termed "zero-order" because it exceeded (by the both duration and magnitude of cycles) what is commonly defined as the "first-order cyclicity" (Read, 1995; Veeken, 2006; Haq, 2014). The entire Phanerozoic global sea-level changes might have represented the only part of any cycle, which have started yet in the Proterozoic. Moreover, it is difficult to predict the number of such "zero" orders. As in the previous case, this preliminary idea requires further development and verification with enough data for establishment of "actual" cyclicity. However, it should not be excluded that the C-order of long-term eustatic cyclicity interpreted for the Paleogene on the basis of the available curves (Haq and Al-Qahtani, 2005; Miller et al., 2005a; Kominz et al., 2008) was not the longest-lived cyclical variations. In such a case, the number of orders may vary (especially if it will be also proved that the Ordovician highstand was larger than that mid-Cretaceous, and that the latter was larger than that early Eocene). Further 
discussions of this issue depend strongly on the interpretation of "actual" eustatic cyclicity and its hierarchy for the Precambrian time intervals; this remains a challenging task to be achieved with the approach of sequence stratigraphy (Eriksson et al., 2004, 2005). Generally, the possibility of the cyclicity orders higher than the C-order established above complicates the understanding of the Paleogene "actual" cyclicity and makes impossible to answer the question about the number of orders of this cyclicity.

\section{Conclusion}

The interpretation of the available global sea-level reconstructions (Haq and Al-Qahtani, 2005; Miller et al., 2005a; Kominz et al., 2008) reveals three orders of long-term eustatic cyclicity that might have operated in the Paleogene. The method of interpretation demonstrated in this paper seems to be powerful for distinction of the "actual" cycles. However, only the highest of these orders is depicted similarly by the interpretations of all chosen original curves. Moreover, there are several objections with regard to the interpreted cycles, and the issue of the number of the Paleogene long-term eustatic cycles remains uncertain because of either nonglobal nature of sea-level changes reconstructed by Haq and Al-Qahtani (2005), Miller et al., 2005a), and Kominz et al. (2008), or "overprint" of the weak global fluctuations by the regional tectonic activity.

Generally, the "actual" long-term eustatic cyclicity in the Paleogene as it is currently known appears to be under question. "New-generation" eustatic curves are very necessary. These should be based on globally-representative stratigraphical data and justified with global-scale modelling of palaeoclimatic and tectonic influences on the sea level. Constraining these curves is a challenge because of the serious lack of uniform stratigraphical data from many regions across the globe. Unfortunately, the now available stratigraphical data are not enough to attempt reconstruction of a new (alternative) eustatic curve like this was done in the case of the 
Paleocene (Ruban et al., 2012). If even there are many data from single outcrops, more important are regionally-representative pieces of information, which requires significant compilation work. Assembly of several well-justified regional syntheses of data would be most helpful for the construction of "new-generation" eustatic curves.

\section{Acknowledgements}

The authors gratefully thank J. Rose (UK) for his editorial support, B. Lovell (UK) for his useful suggestions, and P.G. Eriksson (South Africa), N.M.M. Janssen (Netherlands), B. Lovell (UK), F. Maurer (Qatar), J.F. Read (USA), W. Riegraf (Germany), S.O. Zorina (Russia), and many other colleagues for their advice and/or help with literature. C.P.C. acknowledges support from NSF grant EAR-1151241.

\section{References}

Abreu, V.S., Anderson, J.B., 1998. Glacial eustasy during the Cenozoic: sequence stratigraphic implications. American Association of Petroleum Geologists 82, 1385-1400.

Ali, M.Y., 2009. High resolution calcareous nannofossil biostratigraphy and paleoecology across the Latest Danian Event (LDE) in central Eastern Desert, Egypt. Marine Micropaleontology $72,111-128$.

Alley, N.F., Frakes, L.A., 2003. First known Cretaceous glaciation: Livingston Tillite Member of the Cadnaowie Formation, South Australia. Australian Journal of Earth Sciences 50, 139144.

Anderson, R.S., Anderson, S.P., 2010. Geomorphology: The Mechanics and Chemistry of Landscapes. Cambridge University Press, Cambridge, 637 pp.

Anjos Zerfass, G.S., Ruban, D.A., Chemale, F,. Jr., Zerfass, H., 2013. Cenozoic synthem stratigraphic architecture of the SE Brazilian shelf and its global eustatic context: evidence 
from the Pelotas Basin (offshore Brazil). Geologos 19, 273-290.

Bornemann, A., Norris, R.D., Friedrich, O., Beckmann, B., Schouten, S., Sinninghe Damsté, J.S., Vogel, J., Hofmann, P., Wagner, T., 2008. Isotopic evidence for glaciation during the Cretaceous supergreenhouse. Science 319, 189-192.

Bornemann, A., Schulte, P., Sprong, J., Steurbaut, E., Youssef, M., Speijer, R.P., 2009. Latest Danian carbon isotope anomaly and associated environmental change in the southern Tethys (Nile Basin, Egypt). Journal of the Geological Society 166, 1135-1142.

Boulila, S., Galbrun, B., Miller, K.G., Pekar, S.F., Browning, J.V., Laskar, J., Wright, J.D., 2011. On the origin of Cenozoic and Mesozoic “third-order" eustatic sequences. Earth-Science Reviews 109, 94-112.

Bowen, G.J., 2013. Up in smoke: A role for organic carbon feedbacks in Paleogene hyperthermals. Global and Planetary Change 109, 18-29.

Bowman, V.C., Francis, J.E., Riding, J.B., 2013. Late Cretaceous winter sea ice in Antarctica? Geology 41, 1227-1230.

Brasier, M., 2009. Darwin's Lost World. The Hidden History of Animal Life. Oxford University Press, Oxford, 304 pp.

Catuneanu, O., 2006. Principles of Sequence Stratigraphy. Elsevier, Amsterdam.

Catuneanu, O., Galloway, W.E., Kendall, C.G.St.C., Miall, A.D., Posamentier, H.W., Strasser, A., Tucker, M.E. 2011. Sequence Stratigraphy: Methodology and Nomenclature. Newsletters on Stratigraphy 44, 173-245.

Catuneanu, O., Martins-Neto, M.A., Eriksson, P.G., 2012. Sequence stratigraphic framework and application to the Precambrian. Marine and Petroleum Geology 33, 26-33.

Cherns, L., Wheeley, J.R., Popov, L.E., Ghobadi Pour, M., Owens, M.R., Hemsley, A.R., 2013. Long-period orbital climate forcing in the early Palaeozoic? Journal of the Geological Society, London 170, 707-710. 
Chew, A.E., Oheim, K.B., 2013. Diversity and climate change in the middle-late Wasatchian (early Eocene) Willwood Formation, central Bighorn Basin, Wyoming. Palaeogeography, Palaeoclimatology, Palaeoecology 369, 67-78.

Cogné, J.-P., Humler, E., 2008. Global scale patterns of continental fragmentation: Wilson's cycles as a constraint for long-term sea-level changes. Earth and Planetary Science Letters $273,251-259$.

Cohen, A.S., Coe, A.L., Kemp, D.B., 2007. The Late Palaeocene-Early Eocene and Toarcian (Early Jurassic) carbon isotope excursions: a comparison of their time scales, associated environmental changes, causes and consequences. Journal of the Geological Society, London 164, 1093-1108.

Coltice, N., Rolf, T., Tackley, P.J., 2014. Seafloor spreading evolution in response to continental growth. Geology 42, 235-238.

Conrad, C.P., 2013. The solid earth's influence on sea level. Bulletin of the Geological Society of America 125, 1027-1052.

Coughenour, C.L., Archer, A.W., Lacovara, K.J., 2013. Calculating Earth-Moon system parameters from sub-yearly tidal deposit records: An example from the carboniferous tradewater formation. Sedimentary Geology 295, 67-76.

Eberle, J.J., Fricke, H.C., Humphrey, J.D., Hackett, L., Newbrey, M.G., Hutchinson, J.H., 2010. Seasonal variability in Arctic temperatures during early Eocene time. Earth and Planetary Science Letters 296, 481-486.

Ehlers, J., Gibbard, P.L., 2007. The extent and chronology of Cenozoic Global Glaciation. Quaternary International 164-165, 6-20.

Elrick, M., Reardon, D., Labor, W., Martin, J., Desrochers, A., Pope, M., 2013. Orbital-scale climate change and glacioeustasy during the early Late Ordovician (pre-Hirnantian) determined from $\delta^{18} \mathrm{O}$ values in marine apatite. Geology 41, 775-778. 
Eriksson, P.G., Catuneanu, O., Nelson, D.R., Mueller, W.U., Altermann, W., 2004. Towards a synthesis. In: Eriksson, P.G., Altermann, W., Nelson, D.R., Mueller, W.U., Catuneanu, O. (Eds.), The Precambrian Earth: Tempos and Events. Elsevier, Amsterdam, pp. 739-769.

Eriksson, P.G., Catuneanu, O., Nelson, D.R., Popa, M., 2005. Controls on Precambrian sea level change and sedimentary cyclicity. Sedimentary Geology 176, 43-65.

Eriksson, P.G., Catuneanu, O., Nelson, D.R., Rigby, M.J., Bandopadhyay, P.C., Altermann, W., 2012. Events in the Precambrian history of the Earth: Challenges in discriminating their global significance. Marine and Petroleum Geology 33, 8-25.

Eriksson, P.G., Banerjee, S., Catuneanu, O., Corcoran, P.L., Eriksson, K.A., Hiatt, E.E., Laflamme, M., Lenhardt, N., Long, D.G.F., Miall, A.D., Mints, M.V., Pufahl, P.K., Sarkar, S., Simpson, E.L., Williams, G.E., 2013. Secular changes in sedimentation systems and sequence stratigraphy. Gondwana Research 24, 468-489.

Ernst, W.G., 2007. Speculations on evolution of the terrestrial lithosphere-asthenosphere systemPlumes and plates. Gondwana Research 11, 38-49.

Ernst, W.G., 2009. Archean plate tectonics, rise of Proterozoic supercontinentality and onset of regional, episodic stagnant-lid behavior. Gondwana Research 15, 243-253.

Erwin, D.H., Valentine, J.W., 2013. The Cambrian Explosion: The Construction of Animal Biodiversity. Roberts \& Company, Greenwood, 406 pp.

Evans, D.A.D., 2013. Reconstructing pre-Pangean supercontinents. Geological Society of America Bulletin 125, 1735-1751.

Eyles, N., 2008. Glacio-epochs and the supercontinent cycle after 3.0 Ga: Tectonic boundary conditions for glaciation. Palaeogeography, Palaeoclimatology, Palaeoecology 258, 89-129.

Eyles, N., Januszczak, N., 2004. 'Zipper-rift': a tectonic model for Neoproterozoic glaciations during the breakup of Rodinia after 750 Ma. Earth-Science Reviews 65, 1-73.

Frakes, L.A., Francis, J.E., 1988. A guide to Phanerozoic cold polar climates from high-latitude 
ice-rafting in the Cretaceous. Nature 333, 547-549.

Frakes, L.A., Krassay, A.A., 1992. Discovery of probable ice-rafting in the Late Mesozoic of the Northern Territory and Queensland. Australian Journal of Earth Science 39, 115-119.

Gale, A.S., Voigt, S., Sageman, B.B., Kennedy, W.J., 2008. Eustatic sea-level record for the Cenomanian (Late Cretaceous) - Extension to the Western Interior Basin, USA. Geology 36, 859-862.

Galeotti, S., Rusciadelli, G., Sprovieri, M., Lanci, L., Gaudio, A., Pekar, S., 2009. Sea-level control on facies architecture in the Cenomanian-Coniacian Apulian margin (Western Tethys): A record of glacio-eustatic fluctuations during the Cretaceous greenhouse? Palaeogeography, Palaeoclimatology, Palaeoecology 276, 196-205.

Gargaud, M., Martin, H., López-Garcia, P., Montmerle, T., Pascal, R., 2012. Young Sun, Early Earth and the Origins of Life. Lessons for Astrobiology. Springer, Heidelberg, 299 pp.

Gaucher, C., Sial, A.N., Halverson, G.P., Frimmel, H.E. (Eds.), 2010. Neoproterozoic-Cambrian Tectonics, Global Change and Evolution: A Focus on Southwestern Gondwana. Elsevier, Amsterdam, 466 pp.

Gerya, T., 2014. Precambrian geodynamics: Concepts and models. Gondwana Research 25, 442463.

Gornitz, V. (Ed.), 2009. Encyclopedia of Paleoclimatology and Ancient Environments. Springer, Dordrecht, 1049 pp.

Gradstein, F., Ogg, J., 2004. Geologic Time Scale 2004 - why, how, and where next! Lethaia 37, $175-181$.

Gradstein, F.M., Ogg, J.G., and Smith, A.G., Agterberg, F.P., Bleeker, W., Cooper, R.A., Davydov, V., Gibbard, P., Hinnov, L.A., House, M.R., Lourens, L., Luterbacher, H.P., McArthur, J., Melchin, M.J., Robb, L.J., Shergold, J., Villeneuve, M., Wardlaw, B.R., Ali, J., Brinkhuis, H., Hilgen, F.J., Hooker, J., Howarth, R.J., Knoll, A.H., Laskar, J., Monechi, 
S., Plumb, K.A., Powell, J., Raffi, I., Rohl, U., Sadler, P., Sanfilippo, A., Schmitz, B., Shackleton, N.J., Shields, G.A., Strauss, H., Van Dam, J., van Kolfschoten, T., Veizer, J., Wilson, D., 2004. A Geologic Time Scale 2004. Cambridge University Press, Cambridge, $589 \mathrm{pp}$.

Gradstein, F.M., Ogg, J.G., Schmitz, M., Ogg, G. (Eds.), 2012a. The Geologic Time Scale 2012. Vols. 1-2. Elsevier, Oxford, 1176 pp.

Gradstein, F.M., Ogg, J.G., Hilgen, F.J., 2012b. On the geologic time scale. Newsletters on Stratigraphy $45,171-188$.

Griffin, W.L., Belousova, E.A., O'Neill, C., O'Reilly, S.Y., Malkovets, V., Pearson, N.J., Spetsius, S., Wilde, S.A., 2014. The world turns over: Hadean-Archean crust-mantle evolution. Lithos 189, 2-15.

Guiraud, R., Bosworth, W., Thierry, J., Delplanque, A., 2005. Phanerozoic geological evolution of Northern and Central Africa: An overview. Journal of African Earth Sciences 43, 83-143.

Hallam, A., 1984. Pre-quaternary sea-level changes. Annual Reviews of Earth and Planetary Sciences 12, 205-243.

Hallam, A., 2001. A review of the broad pattern of Jurassic sea-level changes and their possible causes in the light of current knowledge. Palaeogeography, Palaeoclimatology, Palaeoecology 167, 23-37.

Hamilton, W.B., 2011. Plate tectonics began in Neoproterozoic time, and plumes from deep mantle have never operated. Lithos 123, 1-20.

Haq, B.U., 2014. Cretaceous eustasy revisited. Global and Planetary Change 113, 44-58.

Haq, B.U., Al-Qahtani, A.M., 2005. Phanerozoic cycles of sea-level change on the Arabian Platform. GeoArabia 10, 127-160.

Haq, B.U., Schutter, S.R., 2008. A Chronology of Paleozoic Sea-Level Changes. Science 322, 64-68. 
Haq, B.U., Hardenbol, J., Vail, P.R., 1987. Chronology of Fluctuating Sea Levels Since the Triassic. Science 235, 1156-1167.

Hardenbol, J., Thierry, J., Farley, M.B., Jacquin, Th., de Graciansky, P.-C., Vail, P.R., 1998. Mesozoic and Cenozoic sequence Chronostratigraphic framework of European basins. In: de Graciansky, P.-C., Hardenbol, J., Jacquin, Th., Vail, P.R. (Eds.), Mesozoic-Cenozoic Sequence Stratigraphy of European Basins. SEPM Special Publication 60, 3-13, 763-781. Hinnov, L.A., 2013. Cyclostratigraphy and its revolutionizing applications in the earth and planetary sciences. Geological Society of America Bulletin 125, 1703-1734.

Hodgson, E., Grimes, S.T.,Price, G.D., Fitzpatrick, M.E.J., Hart, M.B., Leng, M.J., 2011. Paleogene carbon isotope excursions in the Bunkers Hill borehole: Hampshire Basin, UK. Proceedings of the Geologists' Association 122, 460-471.

Hoffman, P.F., 2013. The Great Oxidation and a Siderian snowball Earth: MIF-S based correlation of Paleoproterozoic glacial epochs. Chemical Geology 362, 143-156.

Hoffman, P.F., Li, Z.-X., 2009. A palaeogeographic context for Neoproterozoic glaciation. Palaeogeography, Palaeoclimatology, Palaeoecology 227, 158-172.

Hoffman, P.F., Kaufman, A.J., Halverson, G.P., Schrag, D.P., 1998. A neoproterozoic snowball earth. Science 281, 1342-1346.

Holmden, C., Mitchell, C.E., LaPorte, D.F., Patterson, W.P., Melchin, M.J., Finney, S.C., 2013. Nd isotope records of late Ordovician sea-level change-Implications for glaciation frequency and global stratigraphic correlation. Palaeogeography, Palaeoclimatology, Palaeoecology 386, 131-144.

Hyland, E.G., Sheldon, N.D., 2013. Coupled CO2-climate response during the Early Eocene Climatic Optimum. Palaeogeography, Palaeoclimatology, Palaeoecology 369, 125-135. Jolley, D.W., Widdowson, M., 2005. Did Paleogene North Atlantic rift-related eruptions drive early Eocene climate cooling? Lithos 79, 355-366. 
Kent, D.V., Cramer, B.S., Lanci, L., Wang, D., Wright, J.D., Van der Voo, R., 2003. A case for a comet impact trigger for the Paleocene/Eocene thermal maximum and carbon isotope excursion. Earth and Planetary Science Letters 211, 13-26.

Kennett, J.P., Stott, L.D., 1991. Abrupt deep-sea warming, paleoceanographic changes and benthic extinctions at the end of the Paleocene. Nature 353, 225-228.

Kirschvink, J.L., 1992. Late Proterozoic low-latitude global glaciation-the Snowball Earth. In: Schopf, J.W., Klein, C. (Eds.), The Proterozoic Biosphere. Cambridge University Press, Cambridge, pp. 51-52.

Kirschvink, J.L., Gaidos, E.J., Bertani, L.E., Beukes, N.J., Gutzmer, J., Maepa, L.N., Steinberger, R.E., 2000. Paleoproterozoic snowball Earth: Extreme climatic and geochemical global change and its biological consequences. Proceedings of the National Academy of Sciences of the United States of America 97, 1400-1405.

Kominz, M.A., Browning, J.V., Miller, K.G., Sugarman, P.J., Mizintseva, S., Scotese, C.R., 2008. Late Cretaceous to Miocene sea-level estimates from the New Jersey and Delaware coastal plain boreholes: an error analysis. Basin Research 20, 211-226.

Komiya, T., Maruyama, S., A very hydrous mantle under the western Pacific region: Implications for formation of marginal basins and style of Archean plate tectonics. Gondwana Research 11, 132-147.

Lemke, P., Ren, J., Alley, R.B., Allison, I., Carrasco, J., Flato, G., Fujii, Y., Kaser, G., Mote, P., Thomas, R.H., Zhang, T., 2007. Observations: Changes in Snow, Ice and Frozen Ground. In: Solomon, S., Qin, D., Manning, M., Chen, Z., Marquis, M., Averyt, K.B., Tignor, M., Miller, H.L. (Eds.), Climate Change 2007: The Physical Science Basis. Contribution of Working Group I to the Fourth Assessment Report of the Intergovernmental Panel on Climate Change. Cambridge University Press, Cambridge, New York, pp. 337-384.

Lovell, B., 2010. A pulse of the planet: regional control of high-frequency changes in relative sea 
level by mantle convection. Journal of the Geological Society 167, 637-648.

Maruyama, S., Sawaki, Y., Ebisuzaki, T., Ikoma, M., Omori, S., Komabayashi, T., 2014. Initiation of leaking Earth: An ultimate trigger of the Cambrian explosion. Gondwana Research 25, 910-944.

Maurer, F., van Buchem, F. S.P., Eberli, G. P., Pierson, B. J., Raven, M. J., Larsen, P.-H., AlHusseini, M.I., Vincent, B., 2013. Late Aptian long-lived glacio-eustatic lowstand recorded on the Arabian Plate. Terra Nova 25, 87-94.

McGowran, B., Holdgate, G.R., Li, Q., Gallagher, S.J., 2004. Cenozoic stratigraphic succession in southeastern Australia. Australian Journal of Earth Sciences 51, 459-496.

Melezhik, V.A., Young, G.M., Eriksson, G.M., Altermann, W., Kump, L.R., Lepland, A., 2013. Huronian-Age Glaciation. In: Melezhik, V.A., Kump, L.R., Fallick, A.E., Strauss, H., Hanski, E.J., Prave, A.R., Lepland, A. (Eds.), Reading the Archive of Earth's Oxygenation. Vol. 3. Global Events and he Fennoscandian Arctic Russia - Drilling Early Earth Project. Springer, Dordrecht, pp. 1059-1109.

Melott, A.L., Bambach, R.K., Petersen, K.D., McArthur, J.M., 2012. An 60-Million-Year Periodicity Is Common to Marine 87Sr/86Sr, Fossil Biodiversity, and Large-Scale Sedimentation: What Does the Periodicity Reflect? Journal of Geology 120, 217-226. Miall, A.D., 1992. Exxon global cycle chart: an event for every occasion? Geology 20, 787-790. Micheels, A., Montenari, M., 2010. A snowball Earth versus a slushball Earth: Results from Neoproterozoic climate modeling sensitivity experiments. Geosphere 4, 401-410. Miller, K.G., Kominz, M.A., Browning, J.V., Wright, J.D., Mountain, G.S., Katz, M.E., Sugarman, P.J., Cramer, B.S., Christie-Blick, N., Pekar, S.F., 2005a. The Phanerozoic Record of Global Sea-Level Change. Science 310, 1293-1298.

Miller, K.G., Wright, J.D., Browning, J.V., 2005b. Visions of ice sheets in a greenhouse world. Marine Geology 217, 215-231. 
Moore, E.A., Kurtz, A.C., 2008. Black carbon in Paleocene-Eocene boundary sediments: A test of biomass combustion as the PETM trigger. Palaeogeography, Palaeoclimatology, Palaeoecology 267, 147-152.

Moriya, K., 2011. Development of the Cretaceous Greenhouse Climate and the Oceanic Thermal Structure. Paleontological Research 15, 77-88.

Moucha, R., Forte, A.M., Mitrovica, J.X., Rowley, D.B., Quere, S., Simmons, N.A., Grand, S.P., 2008. Dynamic topography and long-term sea-level variations: There is no such thing as a stable continental platform. Earth and Planetary Science Letters 271, 101-108.

Müller, R.D., Sdrolias, M., Gaina, C., Steinberger, B., Heine, C., 2008. Long-Term Sea-Level Fluctuations Driven by Ocean Basin Dynamics. Science 319, 1357-1362.

Nance, R.D., Murphy, J.B., 2013. Origins of the supercontinent cycle. Geoscience Frontiers 4, $439-448$.

Nance, R.D., Murphy, J.B., Santosh, M., 2014. The supercontinent cycle: A retrospective essay. Gondwana Research 25, 4-29.

Ogg, J.G., Ogg, G., Gradstein, F.M., 2008. The Concise Geologic Time Scale. Cambridge University Press, Cambridge, 177 pp.

Pearson, P.N., van Dongen, B.E., Nicholas, C.J., Pancost, R.D., Schouten, S., Singano, J.M., Wade, B.S., 2007. Stable warm tropical climate through the Eocene Epoch. Geology 35, 211-214.

Pesonen, L.J., Elming, S.-A., Mertanen, S., Pisarevsky, S., D'Agrella-Filho, M.S., Meert, J.G., Schmidt, P.W., Abrahamsen, N., Bylund, G., 2003. Palaeomagnetic configuration of continents during the Proterozoic. Tectonophysics 375, 289-324.

Peropadre, C., Liesa, C.L., Melendez, N., 2013. High-frequency, moderate to high-amplitude sea-level oscillations during the late Early Aptian: Insights into the Mid-Aptian event (Galve sub-basin, Spain). Sedimentary Geology 294, 233-250. 
Pierrehumbert, R.T., Abbot, D.S., Voigt, A., Koll, D., 2010. Climate of the Neoproterozoic. Annual Review of Earth and Planetary Sciences 39, 417-460.

Polyak, L., Alley, R.B., Andrews, J.T., Brigham-Grette, J., Cronin, T.M., Darby, D.A., Dyke, A.S., Fitzpatrick, J.J., Funder, S., Holland, M., Jennings, A.E., Miller, G.H., O'Regan, M., Savelle, J., Serreze, M., St. John, K., White, J.W.C., Wolff, E., 2010. History of sea ice in the Arctic. Quaternary Science Reviews 29, 1757-1778.

Pujalte, V., Schmitz, B., Baceta, J.I., 2014. Sea-level changes across the Paleocene-Eocene interval in the Spanish Pyrenees, and their possible relationship with North Atlantic magmatism. Palaeogeography, Palaeoclimatology, Palaeoecology 393, 45-60.

Read, J.F., 1995. Milankovitch sea level changes, cycles and reservoirs on carbonate platforms in greenhouse and ice-house worlds. SEPM Short Course Notes 35, 1-102.

Retallack, G.J., 2008. Cool-Climate or Warm-Spike Lateritic Bauxites at High Latitudes? Journal of Geology 116, 558-570.

Roberts, C.D., LeGrande, A.N., Tripati, A.K., 2009. Climate sensitivity to Arctic seaway restriction during the early Paleogene. Earth and Planetary Science Letters 286, 576-585.

Rowley, D.B., Forte, A.M., Moucha, R., Mitrovica, J.X., Simmons, N.A., Grand, S.P., 2013. Dynamic Topography Change of the Eastern United States Since 3 Million Years Ago. Science 340, 1560-1563.

Ruban, D.A., 2010. Do new reconstructions clarify the relationships between the Phanerozoic diversity dynamics of marine invertebrates and long-term eustatic trends? Annales de Paléontologie 96, 51-59.

Ruban, D.A., 2015. Mesozoic long-term eustatic cycles and their uncertain hierarchy. Geoscience Frontiers 6, 503-511.

Ruban, D.A., 2016. A "chaos" of Phanerozoic eustatic curves. Journal of African Earth Sciences $116,225-232$. 
Ruban, D.A., Zorina, S.O., Conrad, C.P., 2010a. No global-scale transgressive-regressive cycles in the Thanetian (Paleocene): Evidence from interregional correlation. Palaeogeography, Palaeoclimatology, Palaeoecology 295, 226-235.

Ruban, D.A., Conrad, C.P., van Loon, A.J., 2010b. The challenge of reconstructing the Phanerozoic sea level and the Pacific Basin tectonics. Geologos 16, 235-243.

Ruban, D.A., Zorina, S.O., Conrad, C.P., Afanasieva, N.I., 2012. In quest of Paleocene globalscale transgressions and regressions: contraints from a synthesis of regional trends. Proceedings of the Geologists' Association 123, 7-18.

Russell, D.A., 2009. Islands in the Cosmos: the evolution of life on land. Indiana University Press, Bloomington, Indianapolis, 456 pp.

Saltzman, M.R., Young, S.A., 2005. Long-lived glaciation in the Late Ordovician? Isotopic and sequence-stratigraphic evidence from western Laurentia. Geology 33, 109-112.

Sames, B., Wagreich, M., Wendler, J.E., Haq, B.U., Conrad, C.P., Melinte-Dobrinescu, M.C., Hu, X., Wendler, I., Wolfgring, E., Yilmaz, I.Ö., Zorina, S.O., 2016. Review: Short-term sea-level changes in a greenhouse world - A view from the Cretaceous. Palaeogeography, Palaeoclimatology, Palaeoecology 441, 393-411.

Santosh, M., 2010. A synopsis of recent conceptual models on supercontinent tectonics in relation to mantle dynamics, life evolution and surface environment. Journal of Geodynamics 50, 116-133.

Seton, M., Müller, R.D., Zahirovic, S., Gaina, C., Torsvik, T., Shephard, G., Talsma, A., Gurnis, M., Turner, M., Maus, S., Chandler, M., 2012. Global continental and ocean basin reconstructions since 200 Ma. Earth-Science Reviews 113, 212-270.

Simmons, M.D., Sharland, P.R., Casey, D.M., Davies, R.B., Sutcliffe, O.E., 2007. Arabian Plate sequence stratigraphy: Potential implications for global chronostratigraphy. GeoArabia 12, 101-130. 
Sluijs, A., Pross, J., Brinkhuis, H., 2005. From greenhouse to icehouse; organic-walled dinoflagellate cysts as paleoenvironmental indicators in the Paleogene. Earth-Science Reviews 68, 281-315.

Sluijs, A., Brinkhuis, H., Crouch, E. M., John, C.M., Handley, L., Munsterman, D., Bohaty, S.M., Zachos, J.C., Reichart, G.-J., Schouten, S., Pancost, R.D., Sinninghe Damsté, J.S., Welters, N.L.D., Lotter, A.F., Dickens, G.R., 2008. Eustatic variations during the PaleoceneEocene greenhouse world. Paleoceanography 23, PA4216.

Spasojevic, S., Liu, L., Gurnis, M., Müller, R.D., 2008. The case for dynamic subsidence of the US east coast since the Eocene. Geophysical Research Letters 35, L08305, doi:10.1029/2008GL033511.

Spasojevic, S., Gurnis, M., 2012. Sea level and vertical motion of continents from dynamic earth models since the Late Cretaceous. American Association of Petroleum Geologists Bulletin 96, 2037-2064.

Strand, K., 2012. Global and continental-scale glaciations on the Precambrian earth. Marine and Petroleum Geology 33, 69-79.

Tang, H., Chen, Y., 2013. Global glaciations and atmospheric change at ca. 2.3 Ga. Geoscience Frontiers 4, 583-596.

Turner, B.R., Armstrong, H.A., Holt, P., 2011. Visions of ice sheets in the early Ordovician greenhouse world: Evidence from the Peninsula Formation, Cape Peninsula, South Africa. Sedimentary Geology 236, 226-238.

Turner, B.R., Armstrong, H.A., Wilson, C.R., Makhlouf, I.M., 2012. High frequency eustatic sea-level changes during the Middle to early Late Ordovician of southern Jordan: Indirect evidence for a Darriwilian Ice Age in Gondwana. Sedimentary Geology 251-252, 34-48.

Turner, S., Rushmer, T., Reagan, M., Moyen, J.-F., 2014. Heading down early on? Start of subduction on Earth. Geology 42, 139-142. 
Vail, P.R., Hardenbol, J., 1979. Sea level changes during Tertiary. Oceanus 22, 71-79.

Veeken, P.C.H., 2006. Seismic Stratigraphy, Basin Analysis and Reservoir Characterisation. Elsevier, Amsterdam, 509 pp.

Weijers, J.W.H., Schouten, S., Sluijs, A., Brinkhuis, H., Sinninghe Damsté, J.S., 2007. Warm arctic continents during the Palaeocene-Eocene thermal maximum. Earth and Planetary Science Letters 261, 230-238.

Wendler, J.E., Wendler, I., 2016. What drove sea-level fluctuations during the mid-Cretaceous greenhouse climate? Palaeogeography, Palaeoclimatology, Palaeoecology 441, 412-419.

Wendler, J.E., Wendler, I., Vogt, C., Kuss, J., 2016. Link between cyclic eustatic sea-level change and continental weathering: Evidence for aquifer-eustasy in the Cretaceous. Palaeogeography, Palaeoclimatology, Palaeoecology 441, 430-437.

Westerhold, T., Röhl, U., McKarren, H.K., Zachos, J.C., 2009. Latest on the absolute age of the Paleocene-Eocene Thermal Maximum (PETM): New insights from exact stratigraphic position of key ash layers +19 and -17. Earth and Planetary Science Letters 287, 412-419.

Yoshida, M., Santosh, M., 2011. Supercontinents, mantle dynamics and plate tectonics: A perspective based on conceptual vs. numerical models. Earth-Science Reviews 105, 1-24.

Young, G.M., 2013. Precambrian supercontinents, glaciations, atmospheric oxygenation, metazoan evolution and an impact that may have changed the second half of Earth history. Geoscience Frontiers 4, 247-261.

Zachos, J., Pagani, M., Sloan, L., Thomas, E., Billups, K., 2001. Trends, Rhythms, and Aberrations in Global Climate 65 Ma to Present. Science 292, 686-693.

Zachos, J.C., Dickens, G.R., Zeebe, R.E., 2008. An early Cenozoic perspective on greenhouse warming and carbon cycle dynamics. Nature 451, 279-283.

Zalasiewicz, J., Williams, M., 2012. The Goldilocks planet. The four billion year story of Earth's climate. Oxford University Press, Oxford, 303 pp. 


\section{FIGURE CAPTIONS}

Fig. 1. The principal modern global sea-level curves. The geologic time scale follows Gradstein et al. (2012a); see also stratigraphy.org for updates. The original eustatic curves are re-scaled. Because of differences in the geologic time scales employed by different authors (see text for additional explanations), the depicted curves should not necessarily match at resolution higher than 5 (usually 1-2) Ma.

Fig. 2. Long-term eustatic cycle interpretations and the palaeoclimatic and tectonic evidence. The simplified geologic time scale follows Gradstein et al. (2012).

Fig. 3. Long-term eustatic cycle interpretations and regional major flooding surfaces (established provisionally on the basis of data from McGowran et al., 2004; Guiraud et al., 2005; Simmons et al., 2007; Gradstein et al., 2012). The simplified geologic time scale follows Gradstein et al. (2012). 


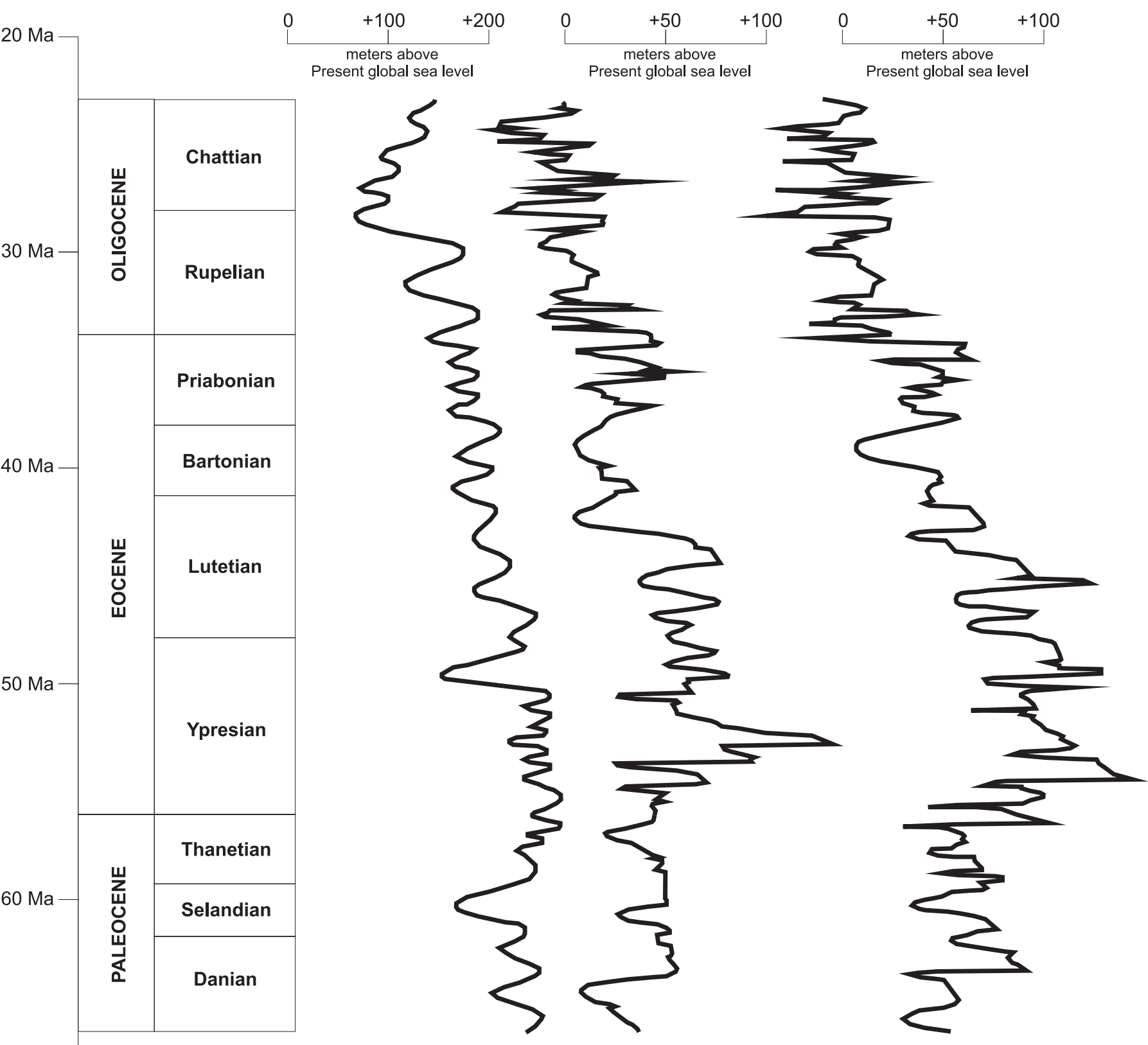


c y c l e o r d e r s

$20 \mathrm{Ma}$
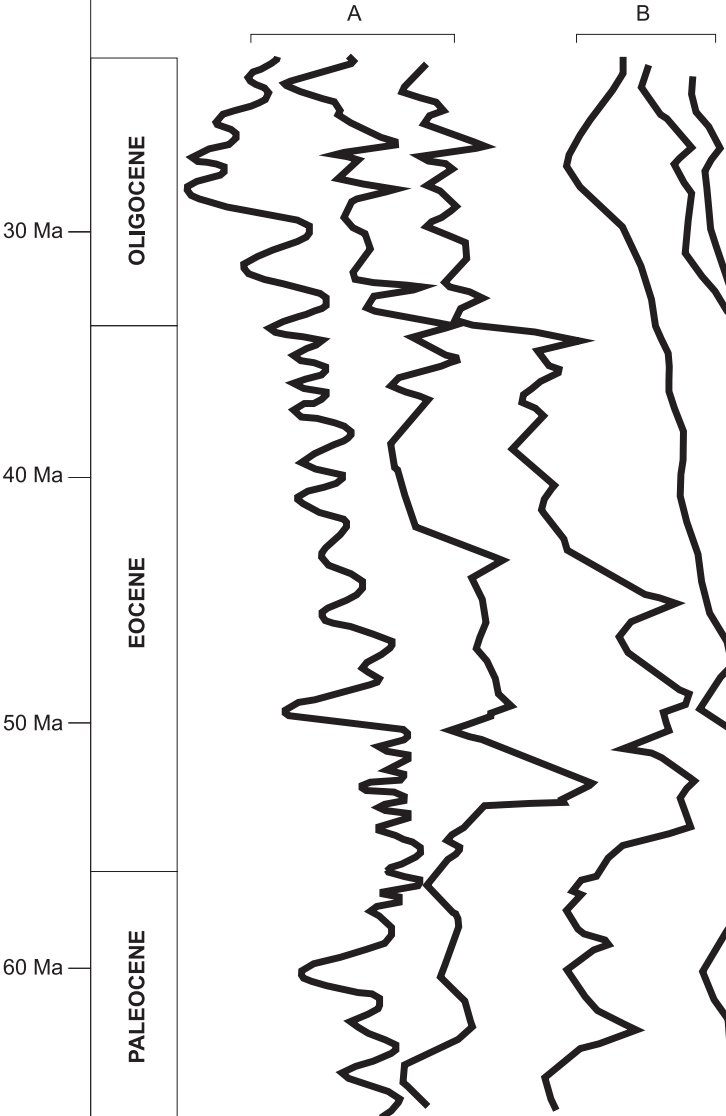

C
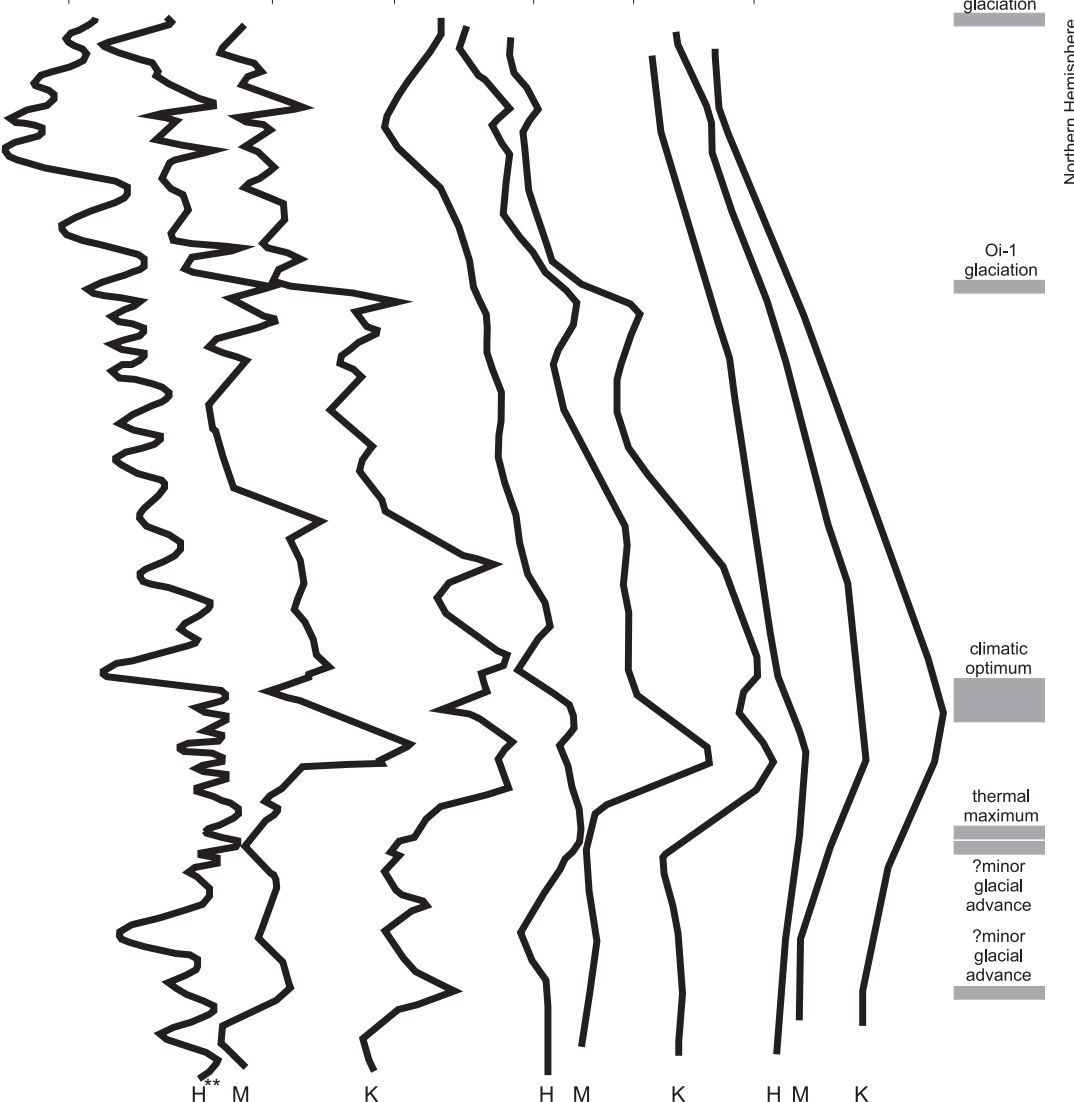

$(2005)$

$\mathrm{H}$ - based on Haq and Al-Qahtani
$\mathrm{M}$ - based on Miller et al. (2005)

$\mathrm{K}$ - based on Kominz et al. (2008)
TECHNICAL NOTE: different length of the curves is linked to the minor restriction of cycle interpretation approach respectively to the geologic time frame
Mi-1

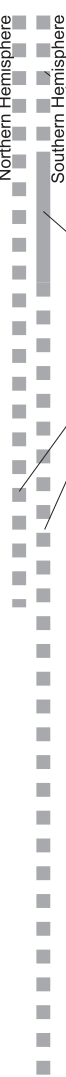

0

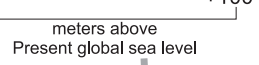

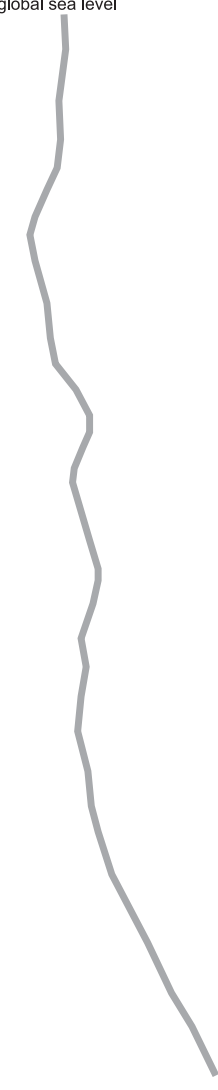

Figure 2 
MAXIMUM FLOODING SURFACES

$20 \mathrm{Ma}$
c y c l e o r d e r s

$30 \mathrm{Ma}$

$40 \mathrm{Ma}$

$60 \mathrm{Ma}$

B $C$

\section{\ulcorner}
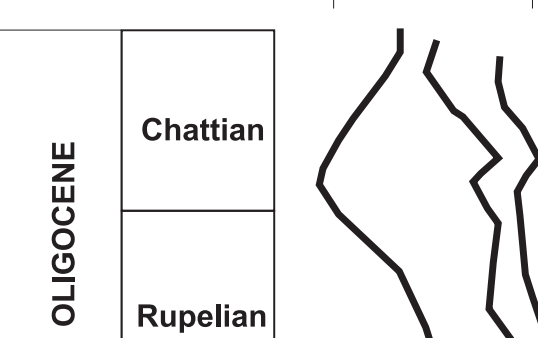

1

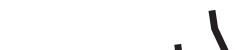

$>$

-

Y

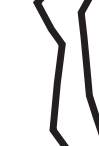

Priabonian

Priabonian

Bartonian

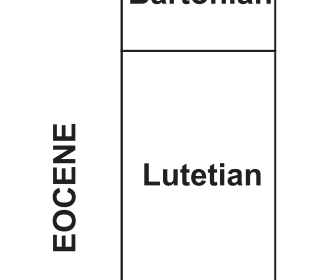

$50 \mathrm{Ma}-$
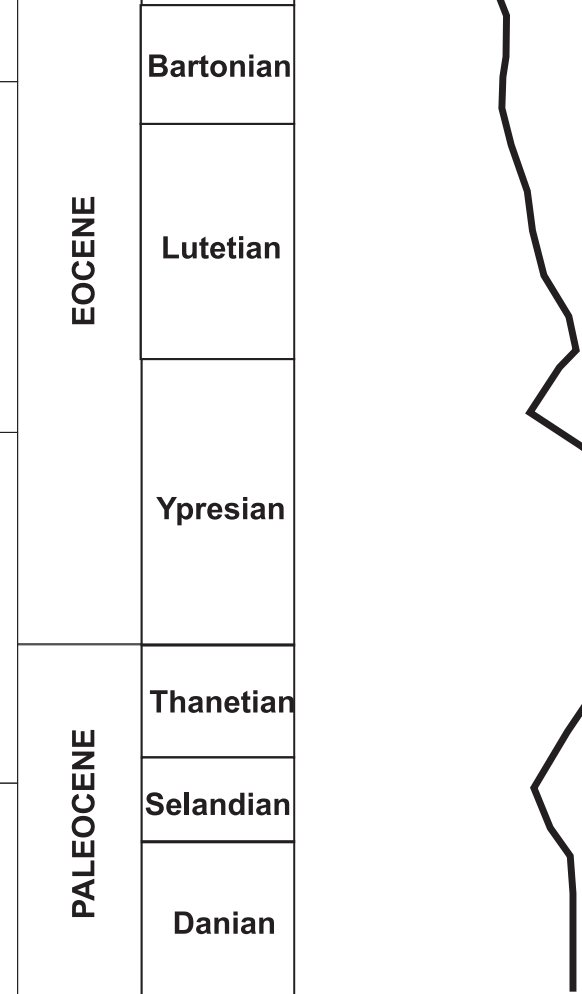

H M
$\mathrm{H}$ - based on Haq and Al-Qahtani (2005)

$\mathrm{M}$ - based on Miller et al. (2005)

$\mathrm{K}$ - based on Kominz et al. (2008)

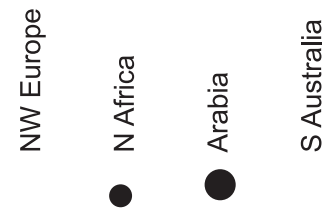

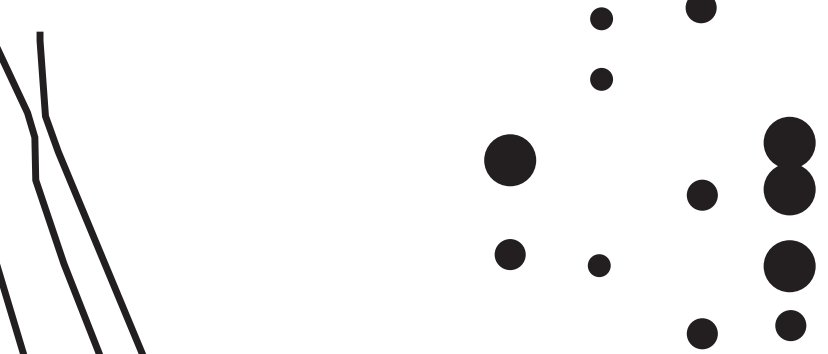

O
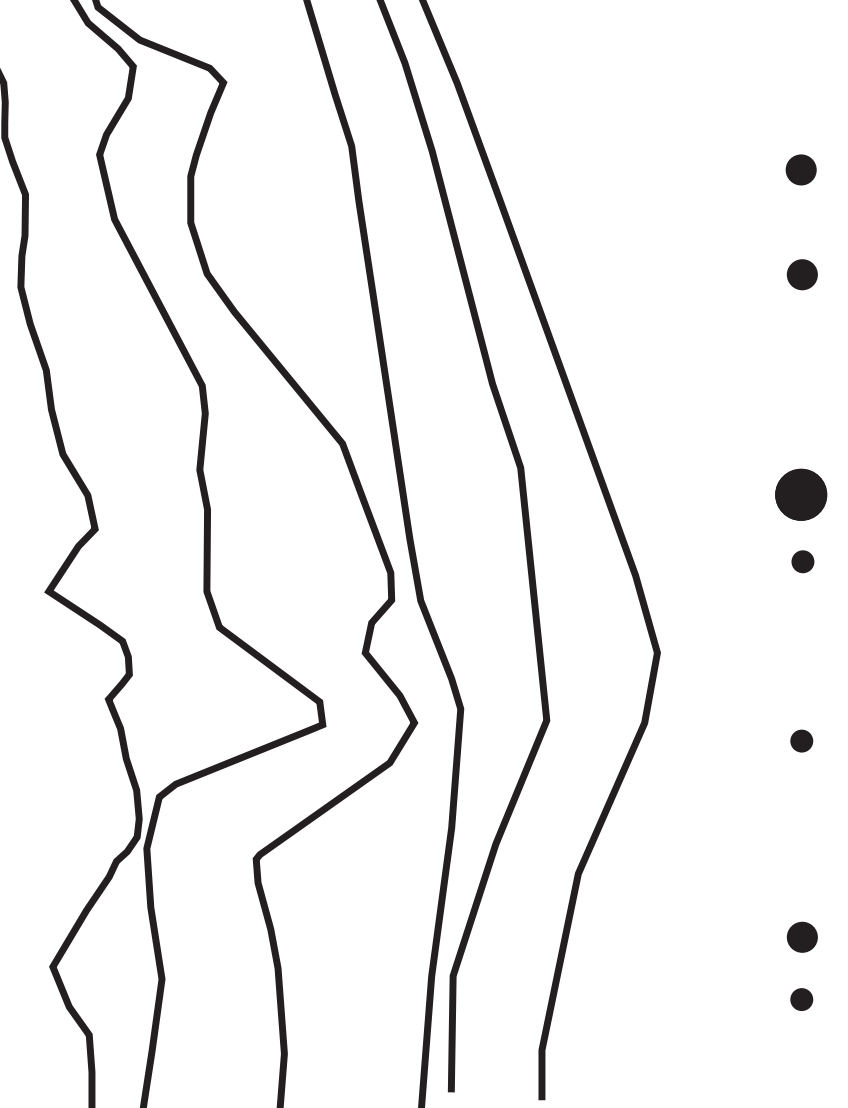

$\mathrm{H} \quad \mathrm{K}$
The size of the circle marks

the relative magnitude of the event. 